\title{
Tropical Fruit Punch Flavor
}

National Cancer Institute

\section{Source}

National Cancer Institute. Tropical Fruit Punch Flavor. NCI Thesaurus. Code C73419.

A characteristic of a medicinal product, specifying that its most predominant agreeable savor detected by the unified sensation of taste and olfactory receptors resembles tropical fruit punch. 